\title{
Fuel for Thought
}

\section{Margaret Hickey}

'If the truth be known, it was not the actual criminal act that I enjoyed. No, no, if the truth be told at all (and it seems that it most definitely will be, judging by the oh-so-serious expression on your handsome face), it was the moments afterward that I enjoyed the best. That moment when my Jimmy Choo would connect with the accelerator and I'd zoom off up the Hume.

'In that moment I'd actually feel my blood coursing through my veins and arteries, toward my heart and back again. I knew every hair on my body personally, and I could feel the very tips of my fingertips. Oh, you laugh at me, you young handsome man - you do, I know! But what do you know of crime really? You know how to direct traffic manually, how to charge someone with assault and how to file a Drunk and Disorderly; but do you really ever know what the 'crim' as you call them, is thinking? Of course not. Not you, with 
your freshly ironed uniform and your shiny badge, not you officer, with your graduation year behind you and your mother as proud as punch. You're clean. But many of your colleagues are not are they? I believe these ones are mostly in the St Kilda station. Not anymore you say? Oh well, they're about. There's a reason our police force is so corrupt - being so close to crime, how can they not want to be a part of it? When they get a delicious whiff, surely most would contemplate giving it a go.

'As for me, well, I'd never considered it. Why would I? A good girl with a striking face brought up in Toorak, graduate of MLC and married to a CEO. Where would I ever get a whiff? Well, as it turns out, at a petrol station.

'Do you like the smell of petrol, officer? By the looks of you I bet you do. You ever take a nice girl out on a motorbike on the weekends? No? Well, you should. You'd look great in leather. Yes, leather - and maybe a little scarf around the neck, no? Oh come on officer, live a little! Is that my tea? Thank you kindly.

'Well, I love the smell of petrol. Being a good girl, I never took drugs, or, how do they say, "chased the dragon?" No, but I loved petrol, my father was involved in the industry. As a small child I'd sniff the stuff till I fainted. I've been burnt by it in more ways than one. You know the smell? It's a strong smell, a heady mix of common oil and rich perfume. It's what first attracted me to my husband you know.

'Well anyway officer, sorry, officers! Welcome to you, what is it? Let me read... Constable Silken! What a name! What a delicious, slinky name. I love it! I want it! But yes, sit down. Next to your colleague. Can I move over a little? No? Oh, have it your own way. 
'So, I was at the petrol station, and I'd filled up the Mercedes. How much did it cost? Oh God, I couldn’t tell. \$100, \$200? Anyway, I went to pay at this little measly counter, and a Magnum ice cream caught my eye. Delicious! I had a sudden vision of myself in Noosa years ago, when I used to eat them by the dozen. So decadent! I didn't have to work on my figure at all then; now, well it takes a little effort. I swim a bit, and take the odd pilates class. You know I can still do the splits? My legs have always been supple; Constable Silken, you agree? These legs of mine are up to your standards? Oh never mind.

'Anyway, I'd bought this Magnum, 'Hazelnut Lust', and in my excitement, I simply did not pay for the petrol. I completely forgot! That night a young officer (with gorgeous arms I recall) came to our house to tell me about the theft. The theft! How it made my husband laugh!

“ "You're a thief Gillian!" he cried, his fat cheeks wobbling with joy, "Gilly's a criminal!" He stood there laughing at me with his stomach heaving about like it was a garbage bag floating on the sea. He hadn't used the fat blaster I'd bought him once, though it cost me the earth to order it from Shanghai. How much shipping? God, I don't know - all I know is that the man who came to drop it off was, well, all man. Tiny little running shorts and a singlet top straight out of a Duran Duran film clip. Not much left to the imagination, if you know what I mean Constable Silken. You ask me how much the fat blaster was? I don't know, all I remember is just a numeral and a few Oh! Oh! Oh's!

'So what I'm trying to say, Officers is that after the first little theft, the one that I did by mistake, I got a taste for it. So simple! You 
buy the paper, smile ever so winningly at the custard-faced cashier, and then you're off? Down the highway at 110k's in your navy blue Mercedes that your husband bought with his Christmas bonus.

'I got sneaky after the first few times, taking different amounts from Power petrol stations all over the state. When CCTV video footage started appearing on the local news and in the papers, I took to wearing a disguise. Nothing too gauche of course: a scarf and enormous glasses, Hepburn style. Later I dyed my hair brown, like Carla Bruni, the new first lady of France. The former model, you know her? Did you know, Constable Silken, that she once claimed that monogamy is not a natural state? She's so brazen, you have to love her.

'I covered the number plate of course too. With what? Do I have to tell you? Can I plead no comment? Oh, very well, but I'm vexed with you all. I covered the number plate with a pair of black lycra slimming underpants. Horrible things, came up to my neck and gave me thrush. I don't want to go on now. No more questions please. I'm cross.

'Look, I must admit, that once I became a hero I couldn't stop. With petrol prices rising all the while, and the press just hammering for the Government to do something, my little escapades became very newsworthy. So, when I learnt how to siphon the petrol from my tank into another (from the internet of course!) I began to dispose of it into other people's cars. It's so easy; you just put your lips over the pipe and blow. Can you imagine Constable Silken? I was a natural. Usually I'd look for an older car - a battered Ford Falcon, or a bruised little Torana. I'd go in the early hours of the morning, just before light. I knew my husband wouldn't miss me. 
He's so fat he uses his own thigh to cuddle if he gets cold.

'You all saw the headlines 'Mysterious brunette - our Robin Hood' and 'Beauty Fools the Petrol Beast' I've got a scrapbook of them somewhere. Look, the story became huge! When that funny looking man, Kochie, from Sunrise put a bounty on my head, I knew I had made it.

'I started using different cars, my husband's, my brother's, my other little Astra. I began noticing things, like how the truck drivers would grimace at the checkout and fathers would tense as they peered at the numbers ticking over on the bowser. One day, I came across a young woman crying at the counter, she didn't have enough money to pay for her fuel. The porridge-faced cashier told her to leave the car at the pump and return when she had some cash. She had two little boys screaming in the back seat - and I offered her a lift home. Why not? I was just there to pay for the paper and drive off; it seemed hardly fair to leave her. After I dropped them home all snivelling and sad I noted the address and returned that night, siphoning petrol into her tank till it was gushing on the driveway like liquid gold.

'As the petrol prices went up my husband whined more and more. "Why do people complain, it's out of my hands," and "the oil companies control the conglomerate, I'm just trying to make a living" and blah blah blah. As usual, I said nothing.

'I knew a little more though. Through my husband's connections I learnt that Power petrol stations were drastically overcharging. They took advantage of the panic in the Middle East and simply raised the prices to support their own luxurious desires. 
'That knowledge spurred me on to greater deeds. I took to collecting petrol in the house, storing it up so I could distribute it how I liked: school buses, taxis, Meals on Wheels vans. I could taste petrol all the time. No amount of brushing and flossing could get rid of it. The heady taste stayed with me all day till I drifted into volatile, technicolour dreams.

'You know the rest, officers. I made the mistake of using my husband's work car one time and the CCTV footage showed the Power logo on the windscreen. Silly of me, I know. But I was getting tired and my thoughts weren't exactly clear.

'So, the police called my husband at his work - the Power headquarters in Melbourne and he came home before they could nab him there. He was in such a rage. Some men, men like Clint Eastwood are attractive when they're angry. Do you get angry Constable Silken? My husband wasn't attractive. Can you imagine a giant vacuum bag, furious beyond all belief? That was him. The old fluff collector really let me have it.

' "What are you doing to me?" he screamed. "I'm the bloody CEO of Power! My own wife is robbing me blind and spreading it all over the news! You're a piece of shit! You're a barren piece of 60 -year-old shit and you can't do anything right! You've never done anything! You think this is funny? You think it's smart? Fuck you, you ugly old hag!"

'I'd walked away by then, but I could still hear him ranting. It didn't worry me too much; I'd heard it all before. Besides, I was busy, as you know. I was dragging the petrol that I'd been stockpiling out of the walk-in robe and pouring it all over the carpet, onto the floorboards and onto the king sized bed. I put on my slinkiest Carla 
Fuel for Thought

Zampatti dress - the tiger print, and my favourite Jimmy Choos. And then, you know, I threw a match.

'Out I walked, out of the house, toward my raving husband, now coloured neon in the light of the fiery blaze. Neighbours started to gather, alarms rang out, traffic stopped and if the truth be told, I'd never felt so hot in all my life.

'We're going? This is goodbye? Could I have another cup of tea? I'm not sure I want to face the press just yet. I've got my own cup here, just use the same bag; I know how financially strained our police force is. Now how do they say? Fill her up.' 